\title{
Iron-bearing minerals from soils developing on volcanic materials from southern Chile. Mineralogical characterization supported by Mössbauer spectroscopy
}

\author{
Carmen Pizarro ${ }^{1,2 *}$, Mauricio Escudey ${ }^{1,2}$, Manuel Gacitua ${ }^{1}$, Jose Domingos Fabris ${ }^{3,4}$
}

${ }^{1}$ Facultad de Química y Biología, USACH, Av. L.B. O'Higgins 3363, Santiago, 7254758, Chile. ${ }^{2}$ Centro para el Desarrollo de la Nanociencia y Nanotecnología (CEDENNA), Av. L.B. O'Higgins 3363, Santiago, 7254758, Chile. ${ }^{3}$ Universidade Federal dos Vales do Jequitinhonha e Mucuri (UFVJM), Campus JK, 39100-000 Diamantina, Minas Gerais, Brazil. ${ }^{4}$ Departamento de Quimica- ICEx, Universidade Federal de Minas Gerais, Campus - Pampulha, 31270-901 Belo Horizonte, Minas Gerais, Brazil.

"Corresponding author: carmen.pizarro@usach.cl

\begin{abstract}
On this work, the iron oxide mineralogy of Chilean volcanic ashes derived soils have been reviewed, emphasizing on new finding linked to the application of Mössbauer spectroscopy. It has been established that free iron oxide layer contributes with positive variable surface charge to the clay-size soil particle, at soil $\mathrm{pH}$. However, the importance of such contribution seems to depend on the evolutionary stage of the different volcanic soil orders, which defines the crystalline degree of their iron oxide contents. Mössbauer spectroscopy complemented with different physical, chemical and instrumental techniques revealed key aspects of iron oxide mineralogy on these Chilean volcanic soils. For instance, results for Ultisol revealed that the evolution of the soil particle could be followed just analysing the main component of their iron oxide mineralogy; thus, the iron oxide mineralogy change when passing from the volcanic ashes (magnetite), to sand-size magnetic separates (partially-oxidized magnetite), to silt-size (strongly-oxidized magnetite), and finally to clay-size (maghemite) soil samples. Therefore, it would seem that physical weathering of the Ultisol produces smaller and more oxidized particles. On the other hand, the Andisol samples, a young volcanic soil compared to Ultisol, seems to have a constant iron oxide mineralogy among all its different particle size fractions: paramagnetic $\mathrm{Fe}^{2+}$ and $\mathrm{Fe}^{3+}$ species with low crystalline degree, the last one possibly assignable to a ferrihydrite-like mineral. Therefore, on the case of Andisols, it seems that the high contents of organic matter somehow prevent mineral evolution towards higher oxidation and more crystalline levels, in agreement with past studies.
\end{abstract}

Keywords: Volcanic soil properties, iron oxide mineralogy, variable surface charge 


\section{Introduction}

Soils derived from volcanic materials are abundant and widespread in central-southern Chile. They are mostly found from latitude $35^{\circ}$ to $45^{\circ}$ south (Figure 1). Most of the Chilean agricultural activities are developed on soils formed on geologically recent volcanic materials (Martínez et al., 2015), which are concentrated on the Mediterranean and the rainy Patagonian soil zone, as described by Fleige et al. (2016). These comprise as much as $60-70 \%$ of all land areas under management or with agronomic potential, more particularly on the Pacific side of the southern cone of the American continent. Actually, many other important agricultural areas worldwide rely on soils developing on volcanic ashes, rocks or pyroclastic fragments, as in Asia (mainly in Japan, Korea, Philippines, Indonesia and Malaysia); relatively lesser occurrences are over a wide geographical scale in Eurasia (including Russian Federation), part of Africa and Oceania (Besoain, 1985; Dahlgren et al., 2004).

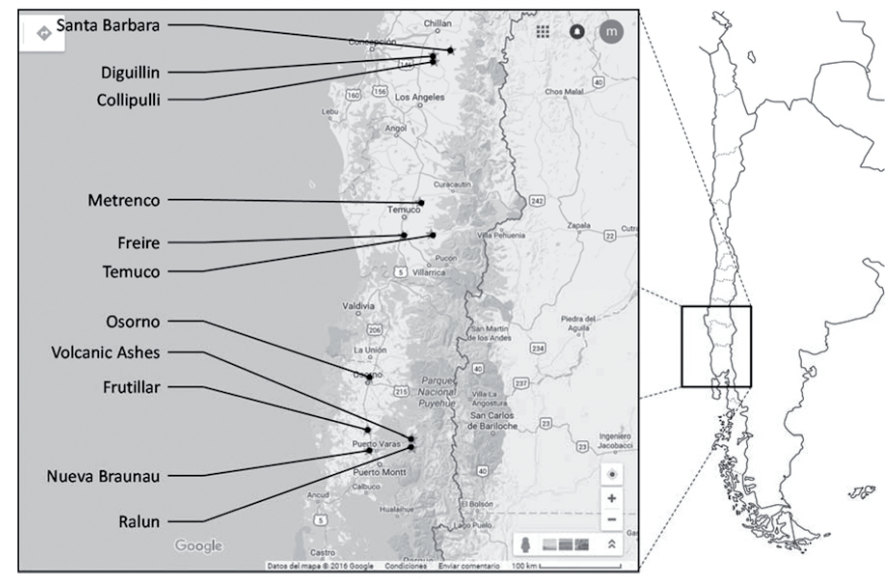

Figure 1. Map representing the geographical location of volcanic soils and volcanic ashes sampling sites. (Map taken from Google Maps)

Andisols and Ultisols, according to the U.S. Soil Taxonomy (Handbook, 2005, and The Twelve Orders of Soil Taxonomy, 2006) are important soil classes from volcanic origin. If compared to Ultisols, Andisols are relatively more recent soils, being characterised by clay mineralogy dominated by non-crystalline or with short-ordered mineral structure (mostly allophane, Escudey et al., 2001). Levard et al. (2012) suggest that the mayor constituent of aluminium-silicate minerals in Andisols is in fact proto-imogolite, a poorly ordered imogolite precursor. Ultisols, on the other hand, are more evolved soils, implying more ordered minerals on their composition (Besoain, 1985, Escudey et al., 2001).

The iron oxides (a broad term, meaning here iron hydroxide, oxyhydroxide or oxide) particles are major components in many soils derived from magmatic materials and greatly influence different properties on these soils. Their occurrence on different types of 
volcanic soils follows the same behaviour for aluminium-silicate minerals, i.e., pedologically moreevolved soils contain iron oxide minerals with overall higher degrees of crystallinity. For instance, reports from Baumgarten et al. (2013) establish that Chilean Andisols have high contents of ferrihydrite, an Fe (III) mineral with low degree of crystallinity. Nevertheless, Pizarro et al. (2003) have proved that, in addition to ferrihydrite, Andisols may also contain many Fe (III) oxides with low crystalline degree that can be easily confused with ferrihydrite. In Ultisols, on the other hand, the content of more ordered iron oxides is more important than in Andisols.

With respect to iron oxide studies made on Chilean volcanic soils, scarce outcomes can be found before the 1990s. First studies were fundamentally based on elemental analyses, X-ray diffractometry (XRD), and indirect measurements of their properties (as selective chemical dissolutive methods). Book chapters authored by Beasoain (1985) included at Suelos Volcanicos de Chile, describe concise elemental analysis of volcanic derived soil samples from central Chile, revealing about a 6-12\% $\left(\mathrm{Fe}_{2} \mathrm{O}_{3}\right)$ of non-crystalline oxides content on Andisol samples, characterised by XRD analysis. Also, same study showed that total iron oxide contents are directly related to the amount of clay fraction on each soil. So, at the time, it seemed that most of Andisols clay presents non-crystalline iron oxide contents, especially in those soils with iron oxide pan and constrained seasonal drainage, which could correspond to ferrihydrite-like minerals. To establish the amount of active $\mathrm{Al}$ and $\mathrm{Fe}$ on clay fraction Sadzawka and Besoain (1981), Galindo et al. (1986) and Grez (1989), independently, used chemical dissolutive methods complemented with infrared differential spectroscopy. These studies are relevant used during classification of Andisols, since, hypothetically, on less evolved soils derived from volcanic ashes, it should predominate Al- and Fe-oxides with low crystalline degree. Then, electrophoretic mobility study published by Escudey and Galindo (1983) on clay samples after removal of the organic matter and iron oxide layer established the importance of iron oxide layer on the variable surface charge characteristics, typical from volcanic derived soils. Consistently, Cornell and Schwertmann (1996) established that this approach provides evidence on the importance and influence of iron oxide in variable charge soils. Therefore, it seems that on young volcanic soils, such as Andisols, clay-size soil fraction contains "humus$\mathrm{Al}$ " and "humus-Fe" complexes which are, in part, responsible of typical variable surface charge characteristic if this soil order. Finally, Escudey and Galindo (1994) showed X-ray diffraction analysis (a technique firstly employed and reported on Chilean samples by Beasoain, 1985) on Chilean soils resulted on mostly in a few broad reflection peaks that do not allow an unambiguous interpretation. It was established that goethite- and hematite-type minerals might also be possibly found on clays or as aggregate material from soils with constrained seasonal drainage. Nevertheless, the mineralogy of volcanic soils was hard to deduce because of the compositional and structural variability of their minerals, particularly of the iron oxide group. Although these studies gave the first hints regarding iron oxides in volcanic soils, these studies provided just incomplete information on its exact composition due to the complex nature of soilrelated iron oxide minerals (which are widely variable on terms of composition, crystalline structure, particle size and morphology). Systematic mineralogical iron oxide characterizations of these matrices attempts were not considered right until the early 2000s. From those years, to the present day, there have been mayor advances, regarding new instrumental techniques and sample preparation methodologies.

Some results on studies made on Chilean volcanic soil would be presented from samples taken from B- 
horizons from pedosystems, located in southern Chile. Their classification corresponds to Ultisols, Andisols, and Andisol with iron oxide pan and constrained sea- sonal drainage. Main characteristics (location, rainfall, annual mean temperature, mineralogy, $\mathrm{pH}$, organic carbon, among others) are summarized in Table 1.

Table 1. General characteristics of Chilean volcanic ash derived soils (Adapted from: Escudey et al., 2004; Mella and Kühne, 1985)

\begin{tabular}{|c|c|c|c|c|c|c|c|}
\hline Soil Order ${ }^{\mathrm{a}}$ & Longitude & Altitude (m) & $\begin{array}{l}\text { Rainfall } \\
\left(\mathrm{m}_{\text {year }}^{-1}\right)\end{array}$ & $\begin{array}{l}\text { Annual mean } \\
\text { temperature }\left({ }^{\circ} \mathrm{C}\right)\end{array}$ & Mineralogy & $\mathrm{pH}^{\mathrm{b}}$ & $\begin{array}{l}\mathrm{OC}^{\mathrm{c}} \\
(\mathrm{wt} \%)\end{array}$ \\
\hline Ultisol & $36^{\circ}-38^{\circ}$ & $120-400$ & $1.2-1.5$ & $14-16$ & $\begin{array}{l}\text { Halloysite } \\
\text { Kaolinite }\end{array}$ & $4.7-5.2$ & $2.0-2.6$ \\
\hline Andisol & $36^{\circ}-41^{\circ}$ & $120-1400$ & $1.2-5.0$ & $10-16$ & Allophane & $4.1-6.2$ & $1.9-9.8$ \\
\hline $\begin{array}{l}\text { Andisol } \\
\text { w/Fe Pan }\end{array}$ & $38^{\circ}-41^{\circ}$ & $80-200$ & $1.5-2.0$ & $13-15$ & Allophane & $4.1-4.4$ & $3.6-7.9$ \\
\hline
\end{tabular}

( ${ }^{\mathrm{a} A c c o r d i n g ~ t o ~ t h e ~ U . S . ~ S o i l ~ T a x o n o m y ~ 2006 .) ~(' I n ~ s u s p e n s i o n ~ o f ~ d o u b l e ~ d i s t i l l e d ~ w a t e r, ~ a t ~ a ~ r a t i o ~ o f ~ 1: 2.5 ~ w / v) ~}$

('Organic matter content determined by the Walkley-Black method (Allison, 1965), using a Radiometer automatic titrator provided with a Pt-calomel combined electrode)

This review is intended to offer a comprehensive picture of the state-of-the-art, minerals, especially iron oxides, found in volcanic soils of Chile. The information would be presented in the following order: (i) Role of surface charges of particles on ions dynamics; surface charge properties; (ii) selected results on the mineralogical analysis of iron oxides on volcanic samples using Mössbauer Spectroscopy as the main characterization tool; and (iii) the effect of the organic matter on chemical stability of iron oxide minerals.

\section{Surface charge of volcanic soils}

An important aspect that has been subject of many studies is the effect of iron oxide on a distinctive characteristic of this type of soils, where variable surface charge mine- rals predominate. Escudey et al. (2004) established that particle surface charge is a key aspect when characterising a soil capacity for adsorbing and releasing charged species, influencing the retention and mobility of plant nutrients and contaminants. For instance, Khawmee et al. (2013) indirectly relate the presence of variable positive surface charge ascribed to the natural iron oxide minerals contents, by analysing electrophoretic mobility of Thai Oxisols and Ultisols samples before and after removal of their iron oxides. Therefore, soil mineralogy alongside with other parameters such as organic matter, define the surface charge nature of volcanic ashes derived soils.

Several approaches may be used to measure and characterise the surface charge; one of them is the isoelectric point (IEP). The IEP is sensitive to changes in the 
external surface of the soil (Parks 1967) and may reflect changes in the organic matter content of variable charged soils (Escudey et al., 2004). Because of the sensitivity of electrophoretic measurements to surface composition of soils, IEP has been used to follow the impact of iron oxides on surface charge of soil particles. The role of iron oxides on the surface charge of volcanic soils needs to be established and isolated from the contribution of organic matter and aluminiumoxides. Escudey et al. (1983) clearly established the positive charge contribution (at soil $\mathrm{pH}$ ) that iron oxides have to the soil particles. Galindo et al. (1992) reported IEP shifts towards positive values after removing the organic matter contents, pointing out the negative contribution to the soil surface charge. This effect is observed to be more pronounced on Andisol over Ultisols, since the first soil order typically contains higher amounts of organic matter and possesses a more "intense" variable charge character (Escudey et al., 2004). Wang et al. (2013) reported that after modification of an Alfisol, an Ultisol and a kaolinite sample with an amorphous Al/Fe hydroxide, the effective negative surface charge density became less negative. The charge contribution of iron oxides on soils is important on many aspects. As an example, Lui et al. (2014) corroborated while relating the amount of bacteria-cells able to adhere over Ultisol particles; he established the possibility that surface charge contribution from iron oxides on Ultisols promotes the number of microorganisms able to adhere on the soil surface. Recent studies by Yan et al. (2015) have established that the positive variable surface charge of iron oxides of red soils from southern China contribute to the corrosive characteristics of this soil towards X80 steel pipelines. An approach for determining such contribution could be the study changes on IEP, when iron oxide coatings are removed from soil particles; the effects of selective dissolution of iron oxides on IEP on soils have to be reviewed (Wada and Harward, 1974; Cavallaro and McBride, 1984). The dithionite-citrate-bicarbonate (DCB) method (Mehra and Jackson, 1958; Jackson, 1985; Singer et al. 1995) is a reported method capable of removing free iron oxides. Free iron oxide refers to the sum of crystalline and non-crystalline content forming a cover over the soil particle (Escudey and Galindo, 1983). Osorno (Andisol) and Collipulli (Ultisol) samples were selected to study the effect of iron content removal on IEP. After the necessary number of DCB treatments on samples, the variation of IEP is followed by electrophoretic mobility studies. Summary of treatment's effect on IEP is shown on Table 2.

Table 2. IEP evolution during chemical treatments

\begin{tabular}{|c|c|c|c|c|c|}
\hline Sample & Untreated & w/o OM & $\begin{array}{l}\text { w/o OM w/o } \\
\text { Fe-ox }\end{array}$ & $\Delta \mathrm{IEP}_{1}$ & $\Delta \mathrm{IEP}_{2}$ \\
\hline & (1) & (2) & (3) & $(2)-(1)$ & $(3)-(2)$ \\
\hline Osorno & 3.3 & 8.8 & 3.2 & +5.5 & -5.6 \\
\hline Collipulli & 2.0 & 6.8 & 2.3 & +4.8 & -4.0 \\
\hline
\end{tabular}


The untreated Osorno clay-size sample, presents a low value of IEP (3.3) due to high organic matter content, typical for these types of soils, which at the soil $\mathrm{pH}$ provides a negative surface variable charge. After OM destruction, the IEP value shifts to alkali values (8.8) denoting the effect of exposing the aluminium and iron oxides to the surface; this mineral layer presents positive variable charge at soil $\mathrm{pH}$. After removing $\mathrm{OM}$ and iron oxides, the IEP of these particles return to acid values (3.2), evidencing that the aluminosilicate core should present negative charge at soil $\mathrm{pH}$. Thus, iron oxides contribute with variable positive surface charge to the soil particle, as several authors have inferred before. Ketrot et al. (2013) determined that the iron oxides contents on several samples of Thai Oxisols and Alfisols were responsible of positive variable surface charge (determined by IEP experiments after removing the organic matter as well). During the preparation of mixtures between soils and different synthetic iron oxide minerals, Li et al. (2013) concluded that the positive charge of several iron oxides (goethite, hematite, amorphous ferrihydrite, etc.) on Alfisols from Nanjing site (China) contribute to the decrease of effective cation exchange capacity and $\mathrm{pH}$ elevation of soils. On the other hand, for Collipulli (Ultisol) inorganic oxide layer contribution is a more important contribution than the organic matter, when compared to Osorno where the IEP change from 2.0 to 6.8 when the OM is destroyed. After removal of iron oxides, the IEP value returns to acid limit (2.3), a lower value than the obtained from Osorno. More important than comparing the IEP values between soils, is the variation of the IEP ( $\triangle$ IEP) between treatments. While removing each layer, the $\triangle \mathrm{IEP}$ values for Osorno where always more intense than those observed for the Collipulli samples. Analogous studies using soil model (synthetic) have arrived to same conclusions. Mora et al. (1992) prepared a synthetic soil model for surface charge studies. They synthesised a low range ordered aluminium-silicate
(AlSi) and applied layers, with different thickness, of iron oxide on it (AlSi/Fe-ox). Then they also applied commercial humic acids (Aldrich) as the organic matter layer (AlSi/Fe-ox/OM). IEP values for AlSi, $\mathrm{AlSi} /$ $\mathrm{Fe}$-ox and $\mathrm{AlSi} / \mathrm{Fe}-\mathrm{ox} / \mathrm{OM}$, gave values of ca. 5.5, 8.6 and 5.6 respectively, thus confirming the observations made for experiments on the reviewed clays. The positive-sign contribution on surface charge from iron oxide is important to prevent accelerated soil acidification from severed weathered soils. Results published by $\mathrm{Li}$ et al. (2012) revealed for several soil lines (Alfisols and Ultisols) from subtropical China, that natural iron oxide contents were direct responsible for preventing further acidification processes through the formation of an electric double-layer over phyllosilicates.

The effect of iron oxide content on soil surface charge has been clarified; this mineral layer may provide positive charge to clay fraction of volcanic soils. Nevertheless, this effect competes with the contribution of OM. On Andisol samples, OM is the most important fraction that determines the surface charge of clays. On Ultisol samples, OM has also an important effect, but is less intense. Here the iron oxide contents play more important role when the contributions to surface charge are determined.

\section{Selected results on the iron oxide mineralogical analysis of volcanic soils from Chile}

Mineralogical analysis of soils iron oxide is a complex process and if solely standard physical methods and the single use of chemical methods give only partial or ambiguous information about the intrinsic nature of soil iron oxide minerals, as affirmed by Pizarro et al. (2000). From a methodological point of view the mineralogical study requires meticulous work, especially in the choice of analytical techniques and in establishing the most adequate experimental conditions (Vandenberghe and De Grave, 2013). 
Some key results of diverse mineralogical analysis of iron-related compounds on representing soils from Chile are next-summarized. Any study focused on iron oxides should consider the use of ${ }^{57} \mathrm{Fe}$ Mössbauer spectroscopy. In spite of ${ }^{57} \mathrm{Fe}$ Mössbauer spectroscopy is known as a powerful analytical tool for iron oxide characterization when soils are involved, some concerns have to be minded before its direct application to the study of iron-minerals from bulk soil samples. As Murad, (2010) explains on its comprehensive review, experiment design should consider sample preparation procedures, e.g. chemical dissolution treatments of the bulk samples, in order to concentrate selected mineralogical phases of interest. Pizarro et al. (2000a) used $5 \mathrm{M} \mathrm{NaOH}$ washes in order to concentrate crystalline iron oxides minerals on soil samples, improving signals recognition on XDR and ${ }^{57} \mathrm{Fe}$ Mössbauer Spectroscopy. DCB method (for removal free iron oxide contents) was employed by Murad et al. (2005) intending to establish the differences between the iron oxide structures at whole bauxite-ore (Brignoles, France) samples from those occluded at the aluminium oxide; such knowledge has potential economic value to metallic aluminium producers. Also, for optimising instrumental experimental conditions, low temperature measurements should be considered during Mössbauer spectrum acquisition. Murad et al. (2005) describes typical ${ }^{57} \mathrm{Fe}$ Mössbauer signals for hematite contained on ore samples observed at 4.2 and $118 \mathrm{~K}$. Also, Murad and Rojik (2005) used $77 \mathrm{~K}{ }^{57} \mathrm{Fe}$ Mössbauer measurements for characterising schwertmannite on acid mine drainage from Sokolov (Czech Republic); at 77 K (Néel temperature) schwertmannite suffers a phase change to a magnetically ordered state, visible through Mössbauer spectroscopy. Finally, mineralogical characterization should be complemented with chemical and physical analysis including conventional methods or point by point electron microprobe spectroscopy, magnetic measurements and powder X-ray diffractometry. Practically all studies reviewed employ many of these complementary methods (Pizarro et al., 2000a; 2000b; 2001; 2003; Murad et al., 2005; Murad and Rojik, 2005; etc.)

As Pizarro et al. (2000a) affirms, main difficulties in soils that mislead Mössbauer analysis are: first, simultaneous mixed-spectra acquisition with paramagnetic (diluted systems) and magnetic (cooperative events between ferro-, ferri- and antiferro-magnetism) contributions; thus, $\mathrm{Fe}^{3+}$ located on octahedral sites of silicate minerals usually presents doublets with similar hyperfine parameters. Second, presence of noncrystalline iron oxide/oxide-hydroxide on volcanic soil samples or superparamagnetic character of finely divided crystalline minerals. Third, isomorphic substitution of iron with elements, such as aluminium, titanium, magnesium, etc., modifies hyperfine parameters of a Mössbauer spectrum. These difficulties sometimes lead to misinterpretations during spectra fitting process. For instance, Saragovi and Mijovilovich (1997) pointed out experimental complications when semiquantitative room temperature Mössbauer analyses were carried out on Mollisol samples with low iron content from Muzzi area (Argentina). Then, Mijovilovich et al. (1999) analysed different Mollisol and Ultisol samples (Bahia Blanca, Argentina) but spectral acquisition was carried out at $15 \mathrm{~K}$ this time, making interpretation possible. Thus, the presence of $\mathrm{Fe}^{+2}$ and $\mathrm{Fe}^{+3}$ isomorphic substitutions on silicate minerals such as illite or montmorillonite for the Mollisol and, for the Ultisol, the clear dominance of hematite and goethite species were established.

Before beginning the descriptions of main outcomes from volcanic soil samples, some results will be introduced on one the most important precursor of volcanic soils: volcanic ashes. The purpose of analysing in more detail the ashes is to establish if there is a relation between the mineralogy of iron oxide 
content of the precursor material and the produced soils. Nevertheless, such conclusion should arrive after presenting the results on different volcanic soil influenced by these ashes on its formative stages.

\section{Iron oxide characterization from volcanic ashes}

According to Silva et al. (2014) volcanic ashes samples were collected from a former lava/ashes effluent from Osorno Volcano. ${ }^{57} \mathrm{Fe}$ Mössbauer spectrum and

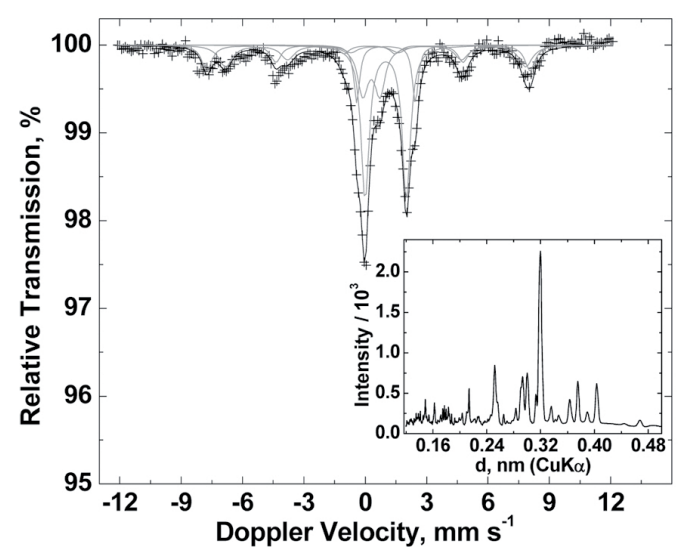

Figure 2. Room temperature ${ }^{57} \mathrm{Fe}$ Mössbauer spectra. Inset: Powder X-ray pattern from volcanic ashes (Adapted from Silva et al., 2014)

From the adjusted model to the Mössbauer spectrum, two magnetic and three paramagnetic contributions were found. The sextets assignation gave the presence of tetrahedral $\mathrm{Fe}^{3+}$ and a mixture of octahedral $\mathrm{Fe}^{2+} \beta^{++}$ ions, which may be attributed to magnetite structure. Doublets are assigned to octahedral $\mathrm{Fe}^{2+}$ and dodecahedral positions of the Fe-diopside-type structure. The presence of $\mathrm{Fe}^{3+}$ doublet may have appeared due to $\mathrm{Fe}^{2+}$ oxidation in the Fe-diopside-type structure.
Results at $80 \mathrm{~K}$ (data not shown) did not gave different information and only confirmed the presence of magnetite as the most relevant contribution to the mineral composition of iron oxides from the ashes.

The proposed mineralogical composition then confirmed by phase search based on data of the powder XRD pattern (Figure 3 (a), Inset). Considering Rietveld refinement of these XRD data with pseudo-Voigt peak fitting gave structural parameters of each crystalline phase. The analysis revealed that the volcanic ashes sample has 79 mass $\%$ of anorthite (ideal formula, $\mathrm{CaAl}_{2} \mathrm{Si}_{2} \mathrm{O}_{8}$ ), 17 mass\% of Fe-diopside-type (CaFe$\left.\mathrm{Si}_{2} \mathrm{O}_{6}\right)$ and 4 mass $\%$ of Ca-magnetite $\left(\mathrm{Fe}_{3-\mathrm{x}} \mathrm{Ca}_{\mathrm{x}} \mathrm{O}_{4}\right)$ contents. Lemouga et al. (2013) also characterised volcanic ashes samples from Foumbot and Djoungo volcanic sites (Cameroon), finding $\mathrm{Fe}^{+2}$ and $\mathrm{Fe}^{+3}$ signals; results complemented well with XDR characterization and minerals were assigned to iron-bearing minerals ferroan forsterite and augite. Comparing these results with those from Osorno volcano, reveal that ashes typically contain mixed valence $\mathrm{Fe}^{2+} / \mathrm{Fe}^{3+}$ compounds, but not necessarily belonging to the same iron oxide minerals. Summing-up, results from ${ }^{57} \mathrm{Fe}$ Mössbauer and XRD crystallography converged and informed that iron oxides mineralogy of volcanic ashes was mainly constituted by magnetite, which is also combined with calcium rich minerals such as anorthite, Fe-diopside-type and Ca-magnetite.

Collipulli (Ultisol), Osorno (Andisol) and Frutillar (Andisol with iron oxide pan and constrained seasonal drainage) soils mineralogical iron oxide characterization attempts are now reviewed employing different approaches (physical separations, selective chemical dissolution methods, among others.) in order to clearly establish the difficulties that had to be dealt for such goal accomplishment. It should be evidenced that direct interpretation of ${ }^{57} \mathrm{Fe}$ Mössbauer spectra of untreated volcanic soil samples does not always permit arrival to concluding results. Therefore, some sample pre-treatment methods are 
discussed and their results analysed for Mössbauer spectra acquisition and interpretation.

\section{Bulk soil and sandy-fraction characterization}

Direct analyses from bulk soil samples gave the first insights on the difficulties that must be dealt with in order to apply Mössbauer Spectroscopy on mineralogical characterizations: spectra interpretation leads to divergent conclusions.

Pizarro et al. (2000a) reported a ${ }^{57} \mathrm{Fe}$ Mössbauer spectra of bulk Collipulli, Osorno and Frutillar soils, Figure 3 .
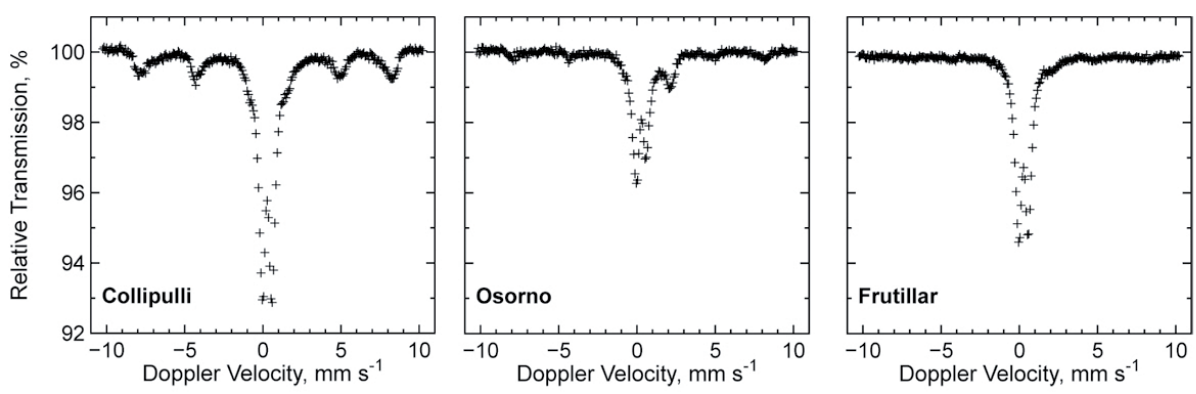

Figure 3. Room temperature ${ }^{57} \mathrm{Fe}$ Mössbauer spectra for Collipulli, Osorno and Frutillar bulk soil samples. (Adapted from Pizarro et al., 2000a)

Similar to the reports by Acebal et al. (2000) data at Figure 4 for all soil samples presents: a central doublet with the highest quadrupolar splitting $\left(\mathrm{Fe}^{2+}\right)$ and a central doublet with the low quadrupolar splitting $\left(\mathrm{Fe}^{3+}\right.$, probably bonded to silicate). Therefore, direct interpretation would allow to describe the presence of magnetite, maghemite, goethite and/or ferrihydrite, preventing the obtainment of concluding mineralogical description of iron oxides contents. The problem comes with fitting. For instance, Collipulli spectrum shows a defined central doublet and a less intense multiplet. Fitting the data with different models accomplishes different interpretations especially on the case of multiplets. As an example, Table 3 summarizes Mössbauer parameters obtained from application of two fitting model to the same spectrum for Collipulli bulk soil sample.
Table 3. Fitting models and Mössbauer hyperfine parameters for Collipulli soil. (Adapted from: Pizarro et al., 2000a)

\begin{tabular}{llllll}
\hline Fitting & $\delta\left(\mathrm{mm} \mathrm{s}^{-1}\right)$ & $2 \varepsilon \mathrm{Q}\left(\mathrm{mms}^{-1}\right)$ & $\mathrm{Bhf}(\mathrm{T})$ & $\mathrm{RA}(\%)$ & $\chi^{2}$ \\
\hline Fitting-A & & & & 0.289 \\
$1^{\text {st }}$ Sextet & 0.011 & 0.200 & 51.30 & 0.002 & \\
$2^{\text {nd }}$ Sextet & 0.314 & -0.172 & 49.91 & 0.020 & \\
$3^{\text {rd }}$ Sextet & 0.321 & -0.001 & 46.69 & 0.026 & \\
$1^{\text {st } D o u b l e t}$ & 0.276 & 0.642 & - & 0.095 & 0.443 \\
\hline Fitting-B & & & & & \\
$1^{\text {st }}$ Sextet & 0.272 & -0.188 & 50.36 & 0.024 & \\
$2^{\text {nd } S e x t e t ~}$ & 0.254 & -0.007 & 46.28 & 0.012 & \\
$3^{\text {rd }}$ Sextet & 0.375 & -0.301 & 38.17 & 0.026 & \\
$1^{\text {st } D o u b l e t ~}$ & 0.273 & 0.654 & - & 0.099 & \\
\hline
\end{tabular}


When the authors adjusted for Fitting-A ( $1^{\text {st }}$ sextet), the highest magnetic field value $(51.30 \mathrm{~T})$ was assigned to hematite. On the other hand, Pizarro et al. (2000a) present that Fittings-B for the same sextet gave a magnetic field value of 50.36, thus adjusting for maghemite. Fittings-A $2^{\text {nd }}$ and $3^{\text {rd }}$ sextets resulted with the lower values of magnetic field, corresponding to magnetite. However, for Fitting-B the value 38.17 $\mathrm{T}$ of $\mathrm{B}_{\mathrm{hf}}$ may be assigned to goethite. Usually the $\chi^{2}$ value is used as criterion for selecting best Fitting (as closer to 1.0 , better is the fit). In this case the highest $\chi^{2}$ value corresponds to Fitting-B. Conversely, best resolution is achieved whit the lowest $\chi^{2}$ value, when Fitting-A is considered. This situation evidences that direct interpretation of ${ }^{57} \mathrm{Fe}$ Mössbauer spectra does not always lead to concluding results. Sometimes, even with appropriate instruments and correct experimental condition, erroneous data interpretation may take place during the fitting process. For instance, Silva et al. (2013) published its results for the characterization of an atypical "Grey Oxisol” (Jequitinhonha River Basin, Minas Gerais, Brazil); Mössbauer data fit described the presence of one paramagnetic $\mathrm{Fe}^{+2}$ contribution with isomer shift ( $\delta) 1.80 \mathrm{~mm} \mathrm{~s}^{-1}$. Then, from the same research group, Silva et al. (2015) published a revision of those results establishing that such isomeric shift value was unrealistically high and they propose a more realistic model considering two paramagnetic $\mathrm{Fe}^{+2}$ with 1.30 and $0.98 \mathrm{~mm} \mathrm{~s}^{-1}$ isomeric shift, respectively. Therefore, is understandable that sometimes a statistically satisfactory fit doesn't necessarily lead to correct interpretation of results. On an attempt to improve results may be select of different particle sizes. However, as the same report demonstrated (Pizarro et al., 2000a) sandy fraction samples did not show significant differences with the respective spectra (Data not shown) of bulk soil samples. Thus, just separation by size fraction doesn't allow clear description of iron oxide/hydroxi-oxide composition either.
From an experimental point of view, the study of iron oxides in volcanic soils requires the establishment of more aggressive strategies for accurately resolving its composition. Such strategies may involve physical pre-treatments and/or chemical selective concentration of mineral phases of interest. Due to the ambiguous results, magnetic separates of sandy fraction were analysed. Results presentations continue with the magnetic separates.

\section{Magnetic separates from sandy-fraction}

For further characterization of iron-oxide composition on soil samples, several analyses were considered on its magnetic separates. According to reports from Pizarro et al. (2001) sand fractions are quite well separable into magnetic and non-magnetic sub-fractions by suspending the sample in water, and picking up magnetic particles with a hand-held magnet. In the present section, Mössbauer spectroscopy is complemented with analysis from, saturation magnetisation measurements, X-ray diffraction, microprobe analysis and optical microscopy techniques.

Results on saturation magnetisation measurements, $\sigma$, for magnetic separates from Collipulli, Osorno and Frutillar samples were 38.2, 26.4 and $1.5 \mathrm{~J} \mathrm{~T}^{-1} \mathrm{~kg}^{-1}$, respectively. Collipulli (Ultisol) presents the highest value possibly due to the higher content of magnetic materials. Recently, magnetic measurements have been employed by other authors in order to characterise volcanic soils from the eastern part of French Massif Central. Grison et al. (2015) proposed to establish relationships between magnetic susceptibility measurements and chemical parameters from magnetic soils in order to define "andic" properties of a certain volcanic soil. Moreover, they propose that magnetic and chemical parameters can be related to pedogenesis factors on Andisols (Grison et al., 2016). Despite such relationships may explain the origin of soils and 
their evolution from parent material, magnetic measurement solely cannot be thrusted when comes to characterization of iron oxides mineralogy, considering that iron oxides are not the only minerals with magnetic properties. Algoe et al. (2012), state that in many occasions the most magnetic fraction of soils is directly related to higher contents of more crystalline character iron oxides, such as magnetite. Even more, if titanomagnetite is also present within soil samples a direct relationship between magnetism and crystalline degree cannot be established. Therefore, in order to corroborate that magnetic character of Collipulli samples corresponds to magnetic crystalline iron oxide minerals contents, further experiments must be considered. Room temperature zero-field ${ }^{57} \mathrm{Fe}$ Mössbauer spectra for magnetic separates of Collipulli soil samples are presented on Figure 4.

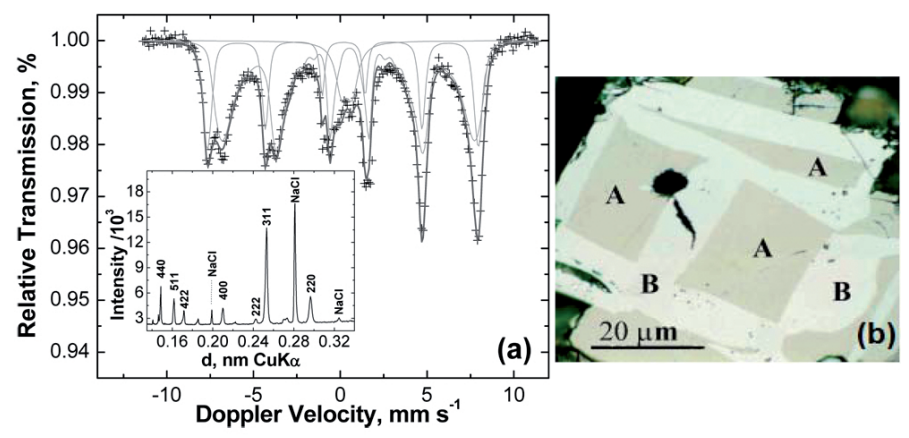

Figure 4. Room temperature ${ }^{57} \mathrm{Fe}$ Mössbauer spectra of magnetic separate from the sand fraction of Collipulli samples. Inset: Powder X-ray patterns. Miller indexes for the main reflection planes of the cubic iron oxide spinel structure are indicated. $\mathrm{NaCl}=$ internal standard (a).Optical microscopy image with common patterns of polished section in the magnetic extract of sand fraction (b) (Adapted from: Pizarro et al., 2001).

Fitting this Mössbauer spectrum with a model-independent hyperfine field distribution leads to two distribution blocks. One of these presents characteristic for the mixed valence $\mathrm{Fe}^{3+}{ }^{2+}$ in the octahedral site of magnetite and has a maximum $\mathrm{B}_{\mathrm{hf}}$ at $48.3 \mathrm{~T}$, representing $58 \%$ of the relative spectral area RA\% (see more details at Pizarro et al., 2001). Causevic et al. (2004) reported similar results on an Argentinian Ultisol located on a sub-tropical region, finding high contents of magnetite on the magnetic separates from the sand fraction.
Powder X-ray diffraction results, Figure 4 (a)-Inset, reveal that the magnetic separates contain a complex mixture of phases, dominated by iron oxide spinels. Split peaks are observed for several reflections. A closer look at the highest intensity 311-reflection of the spinel structure revealed several maxima centred at d-spacing with characteristic values ranging from cubic maghemite (JCPDS; card \# 24-81) to magnetite (JCPDS card \# 19-629). Optical micrograph analysis, Figure 4 (b), also complemented the results obtained on Collipulli magnetic separates; typical iron oxide 
spinels are recognized. Nevertheless, the magnetic particle contains different domains. It has two different regular patterns of darker (A) and lighter (B) areas. Both of these areas are designated to magnetite, in agreement with the respective ${ }^{57} \mathrm{Fe}$ Mössbauer spectrum, of different chemical composition.

Domain chemical composition was elucidated by means of microprobe analysis, revealing wide range of chemical composition of the spinel phases (usually point composition data is taken from three to five optically similar zones of different grains). From this analysis, magnetic separates for Collipulli samples showed a large variability on chemical composition. Microprobe analysis dark areas (point A) for Collipulli image, Figure 4 (b), gave an averaged formula:

$\left(\mathrm{Fe}^{2+/ 3+}\right)_{2,43} \mathrm{Al}_{0.26}^{3+} \mathrm{Mg}_{0,02}^{2+} \mathrm{Mn}_{0.02}^{2+} \mathrm{Ti}_{0.07}^{4+} \square_{0.02} \mathrm{O}_{4}$

were $\square$ corresponds to a vacancy. The molar mass (M) for the dark areas (Figure 4b), was determined as $216.2 \mathrm{~g} \mathrm{~mol}^{-1}$. Lighter areas (point B) correspond to

$\left(\mathrm{Fe}^{2+/ 3+}\right)_{2.05} \mathrm{Al}_{0.05}^{3+} \mathrm{Mg}_{0.11}^{2+} \mathrm{Ti}_{0.54}^{4+} \square_{0.25} \mathrm{O}_{4}$

with molar mass of $\mathrm{M}=208.6 \mathrm{~g} \mathrm{~mol}^{-1}$. Titanium content on spinels varies from $<1$ to $\sim 0.6$, but $\sim 0.3$ is more frequent. Magnesium content are also variable on spinels reaching indexes of $\sim 0.1$. Fabris et al. (1997) has described such a configuration (a Ti-, Mgrich spinel) before on tuffite samples, a rock formed from volcanic ashes (and its corresponding soil) in Brazil with comparative $\mathrm{Mg}$ contents. Therefore, such as Algoe et al. (2012) said, the presence of titanomagnetite prevents the use of magnetic measurements for mineralogical characterization of iron oxide minerals. A qualitative analysis presented by Pizarro et al. (2001) of ${ }^{57} \mathrm{Fe}$ Mössbauer spectra of Andisol magnetic separates samples revealed the presence magnetic ordering when acquisition is made at low temperature. The Mössbauer spectra magnetic separates from sand-size fraction of Osorno soil showed superpara- magnetic behaviour at $80 \mathrm{~K}$ spectra, while for those from Frutillar soil presented a dominant paramagnetic phase (presumed as silicate bonded $\mathrm{Fe}^{3+}$ ) with less magnetic ordering effect at $80 \mathrm{~K}$ measurements. There's also the possibility that magnetic separates from sand-size fraction of Frutillar soil samples contains iron oxide particles much finer than those from Osorno, requiring lower temperatures for correct Mössbauer spectra interpretation.

Results on magnetics separates gave more insights regarding the composition of iron oxides. It was established that, similar to the observed on Osorno volcano ashes (Silva et al., 2014), partially oxidized magnetite contributed importantly to the iron oxide/-oxyhydroxide contents of the sandy fraction from analysed volcanic soils. Nevertheless, it was impossible to obtain magnetic separates from finer fractions (silt and clay, respectively) using solely physical methods. Direct interpretation of ${ }^{57} \mathrm{Fe}$ Mossbauer spectra from these finer fractions (data not shown) also leads to inconclusive results. Possibly, the presence of a layer of poorly crystalline iron oxides hinders clear interpretation of data on these fractions. The next step corresponded to analyse the effect of chemical treatments (treatments with the scope of non-crystalline layer removal) on the mineralogical characterization of iron oxide content on finer fractions.

\section{Chemically treated silt and clay fractions}

Murad (2010) reviewing the mineral constituents on clays and soils, established that soils developed under moderate climate conditions may not only present spectral intricacy due to complex mineralogy, but also may show superparamagnetism bellow $77 \mathrm{~K}$ due to the presence of Fe oxide nanoparticles. On these cases, selective chemical dissolution treatments are optional, sometimes essential, strategies to improve the mineralogical analysis of soil samples. How- 
ever, no chemical extractive solution, regardless of its nature, would dissolve completely certain species, while leaving unaffected others. For instance, iron oxide/-oxyhydroxides are mostly presented as a continuum of inter-related mineral forms (assemblages of strongly cemented multiphase grains in heterogeneous systems) with a considerable range of crystalline degree. Cornell and Schwertmann (1996) reviewed some of the typically used methods to concentrate and/or to selectively dissolve some mineral species. Among all methods, some of the most conventional procedures are:

(i) Norrish and Taylor (1961) first, and Kämpf and Schwertmann (1982) later, reported the use of sodium hydroxide $(\mathrm{NaOH})$ washes for concentration of crystalline mineral phases, preferentially removing silicate and gibbsite.

(ii) Blesa et al. (1987) reported that ammonium oxalate (AOX) treatment is effective and simple for removing magnetite, dioctahedral layer silicates, allophane, and, when the procedure is carried out in the absence of light, poorly crystallized iron oxide in soils (McKeague and Day, 1966; Schwertmann, 1973; Blume and Schwertmann, 1969). Nowadays is known that AOX treatment is able to remove poorly crystalline iron contents.

(iii) Mehra and Jackson (1958) reported for the first time that dithionite-citrate-bicarbonate (DCB, already mentioned on surface charge studies) removes free iron oxides. Later, Singer et al. (1995) specified that DCB method preferentially attacks pedogenic maghemite over lithogenic magnetite. The DCB method does not remove the Fe oxide contained within the aluminium-silicate core and of those from isomorphic substitution onto phyllosilicate structures.

Reyes and Torrent (1997) reported that sodium citrate - ascorbic acid (CA), in spite of the relatively weak reducing and complexing character of ascorbate, selectively extracts poorly crystalline iron oxides.

\section{Sodium hydroxide $(\mathrm{NaOH})$ treatment of silt fraction.}

As reported, silicates, aluminium-silicates and organic matter in silt and clay fractions may be removed by extractions of concentrated heated $\mathrm{NaOH}$ (i.e., $5 \mathrm{M}$ and $90{ }^{\circ} \mathrm{C}$ for 1 hour) (Norrish and Taylor, 1961). The solid residue is then neutralized and cleansed with diluted hydrochloric acid. Such chemical treatment should dissolve non-crystalline Fe oxides, Fe-organic matter complexes, silicates and gibbsite. It also should concentrate magnetic and crystalline $\mathrm{Fe}$ compounds at the solid phase. This approach has been extensively employed for the mineralogical characterization of iron oxides and a high level lof expertise has been demonstrated by Brazilian researches on the subject. Ferreira et al. (2003) employed the alkali treatment on samples of a Red Nitossolo developing on a tholeiitic basalt, finding maghemite on the sand and ferric ilmenite at the silt. Finally, Anastacio et al. (2005) employed $\mathrm{NaOH}$ washes on clay-size fraction from a Brazilian Cambisol, describing the formation of maghemite and superparamagnetic goethite. This bibliographic data give accounts on the expectable improvements on signal quality of the ${ }^{57} \mathrm{Fe}$ Mössbauer spectra for correct interpretation of results. Collipulli silt-size fraction Mössbauer spectra are presented on Figure 5, complement with X-ray diffractometry; results proved that after three sequential $\mathrm{NaOH}$ treatments spectra quality was clearly improved (Pizarro et al., 2000b). For the untreated silt an incipient magnetic hyperfine structure may be observed, which cannot be ascribed to any known iron oxide mineral. On the other hand, the same silt sample after three sequential $\mathrm{NaOH}$ treatments presents typical Mössbauer signals of strongly oxidized magnetite. Fitting parameters from adjusted model considered two subspectra. 
(a)

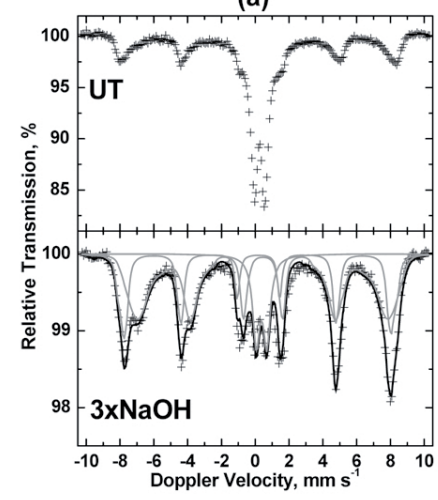

(b)

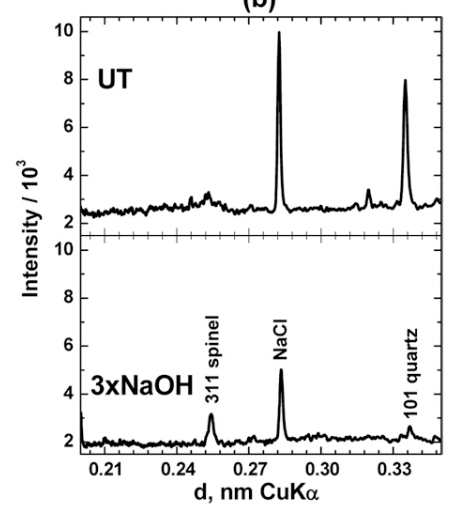

Figure 5. Room temperature ${ }^{57} \mathrm{FeMössbauer} \mathrm{spectra} \mathrm{(a).} \mathrm{Power} \mathrm{X}$ ray patterns with $\mathrm{NaCl}$ as internal standard (b). Analysed samples corresponded to untreated (UT) and after three sequential $\mathrm{NaOH}(3 \times \mathrm{NaOH})$ treatments of Collipulli silt fraction (Adapted from: Pizarro et al., 2000b)

The first corresponded to magnetically ordered phase with characteristic mixed-valence $\mathrm{Fe}^{2+} \beta^{3+}$ in octahedral site of magnetite with an isomeric shift $(\delta)$ of $0.059 \mathrm{~mm} \mathrm{~s}^{-1}$ a quadrupole splitting $(2 \varepsilon \mathrm{Q})$ of 0.020 $\mathrm{mm} \mathrm{s}^{-1}$ and a maximum of magnetic field $\left(\mathrm{B}_{\mathrm{hf}}\right)$ of 46.2 $\mathrm{T}$, representing $39 \%$ of the relative spectral area (RA) (Pizarro et al., 2000b). The second, to a central doublet describing $\mathrm{Fe}^{3+}$ in tetrahedral sites with an $\delta$ of $0.30 \mathrm{~mm} \mathrm{~s}^{-1}$, a $2 \varepsilon \mathrm{Q}$ of $-0.040 \mathrm{~mm} \mathrm{~s}^{-1}$ and $\mathrm{B}_{\mathrm{hf}}$ of $48.2 \mathrm{~T}$ corresponding to $26 \%$ of RA (Pizarro et al., 2000b). Therefore, $\mathrm{NaOH}$-treatment was an effective tool for concentrating iron oxide in the studied pedomaterials, revealing an important strategy on volcanic soil sample preparation for mineralogical analysis. These observations were complemented with the results on the corresponding sets of X-ray patterns, presented at Figure 5 (b). Treatment effects are evidenced by characteristic signals changes such as the intensity ratio between the 311 reflection of cubic Fe-rich spinels and the 101 reflection of quartz. The increasing intensity ratio can be semi-quantitatively ascribed to the relative enrichment of iron oxides in the sample. The $\mathrm{NaOH}$ treatments on Andisol silt samples were also improved from the point of view of feasible interpretation of the respective spectra. Pizarro et al. (2000b) reports that Mössbauer spectra of silt fractions of Osorno (Andisol) present similar behaviour. Untreated sample spectrum shows low resolution for solving the hyperfine parameters after data fitting. However, after three $\mathrm{NaOH}$ treatments hyperfine parameters become noticeable, and its fit (data not shown) presents a wide central doublet, corresponding to some paramagnetic or superparamagnetic $\mathrm{Fe}^{2+}$ and $\mathrm{Fe}^{3+}$ species, the last one assignable to ferrihydrite-like minerals, plausible intrinsically bonded to silicate structures which are not soluble during the $\mathrm{NaOH}$ selective dissolutive treatment. There is also an incipient resonant sixline signal assignable to some hyperfine structure of crystalline iron oxide, probably due to the presence of hematite or maghemite. Despite the improvement on the results, $\mathrm{NaOH}$ treatment was less effective for Andisol than for Ultisol samples. This basic treatment concentrate crystalline iron oxides while removing active iron oxides bonded to aluminium-silicate, thus leaving few iron-related materials for analysis on less evolved soils such as Andisols. 
Therefore, the alkaline treatment permitted a more conclusive interpretation of results from ${ }^{57} \mathrm{Fe}$ Mössbauer spectroscopy and X-ray diffractometry for volcanic soils, especially for Ultisol sample. On this sense, silt fraction from Collipulli presented strongly oxidized magnetite as the most important iron mineral specie. Since magnetic sandy separates for the same soil presented partially oxidized magnetite as the most important iron mineral, it would seem that, during soil formation stages as higher the physical weathering level gets, producing smaller and more labile particles, chemical weathering also gets promoted. At similar conclusion was arrived from analyses of topsoils from the volcanic Brava Island, Cape Verde (Marques et al., 2016). The authors found more crystalline strongly oxidized iron oxides (such as hematite, oxidized magnetite and maghemite), located at the oldest and most weathered fractions of the studied pedons. However, when analysing silt fraction of Osorno soil (Andisol) the most important constituent is a ferrhydrite-like mineral with low crystalline character (Pizarro et al., 2000b). Comparing the results between Andisol against Ultisol, the second is characterised as an older volcanic material soil with low organic matter content, and with iron-oxide minerals of higher crystalline degree. To similar conclusions arrived Marques et al. (2016) for topsoil from Brava Island. Further experimentations were required to elucidate mineralogical composition of the fine fraction. Next step is reviewing results from chemical treatments for removal of non-crystalline iron oxide on clay fractions, and the interpretation of Mössbauer results.

\section{Ammonium oxalate (AOX), citrate-ascorbate (CA) and dithionite-citrate bicarbonate (DCB) chemical treatments on clay fraction.}

Report from Pizarro et al. (2008b) revealed that ammonium oxalate (AOX) and citrate-ascorbate (CA) treatments may be used to selectively eliminate poorly crystalline iron oxides, thus improving the ${ }^{57} \mathrm{Fe}$ Mössbauer spectra during mineralogical analysis of Collipulli silt and clay fractions. These results are complemented with elemental analyses and scanning electron microscopy (SEM) imaging, in order to check up the effect of chemical treatments on the composition and morphology of clay particles. In AOX procedure, soil samples, in darkness, are treated with a mixture of oxalic acid and ammonium oxalate during 4 hours at $\mathrm{pH}$ 3. AOX treatment has been employed to improve Mössbauer quality. A report from Komadel et al. (1998) determined that goethite mineral persisted after AOX treatment of an Fe-rich bentonite sample, but the Mössbauer spectra interpretation permitted to deduce that some isomorphic substitutions of Al-for-Fe was achieved after the reductive treatment. On the other hand, Acebal et al. (2000) proved that for Mollisol samples the AOX treatment is able to extract poorly crystalline iron oxide from the finest soils fractions, leaving them intact at the coarse grains. Results published by Karltun et al. (2000) also pointed out that after treating podzolised forest soil samples with AOX, Mössbauer spectra showed that a (super) paramagnetic $\mathrm{Fe}^{+3}$ phase (probably ferrihydrite) was effectively removed.

The CA treatment uses, in darkness, a mixture of sodium citrate/ascorbate for $16 \mathrm{~h}$ at $\mathrm{pH}$ 6. On the past, this procedure has been applied in studies regarding the effects $\mathrm{Fe}$ mobility for assessing possible Fechlorosis (iron deficiency) on crops (De la Torre et al., 2010), proving that this methodology efficiently leaches poorly crystalline forms of iron.

${ }^{57} \mathrm{Fe}$ Mössbauer spectra acquisition for clay-size soil fractions, after AOX and CA treates, were carried out at $6 \mathrm{~K}$, allowing a better interpretation when compared to room-temperature ones; most of the 
superparamagnetic relaxation effects are suppressed. Figure 6 (a), presents adjusted spectra for

(a)

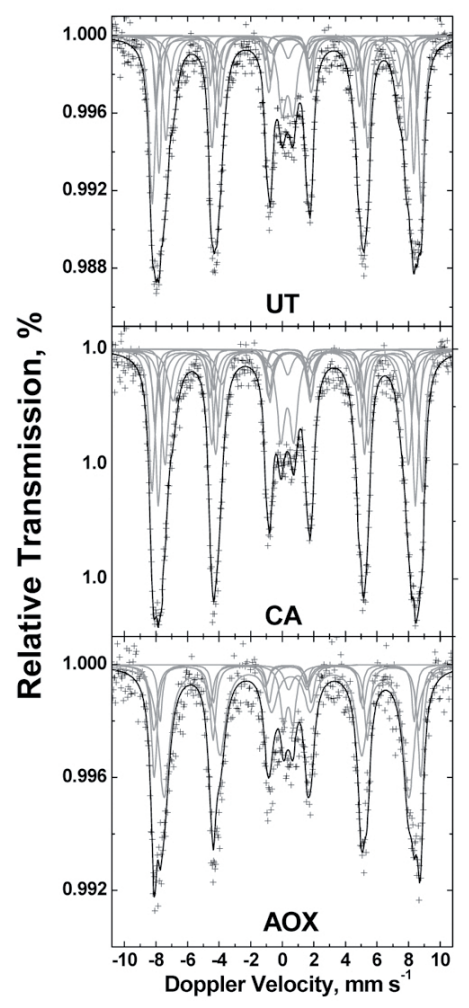

AOX and CA treatments explained above, Pizarro et al. (2008b). (b)
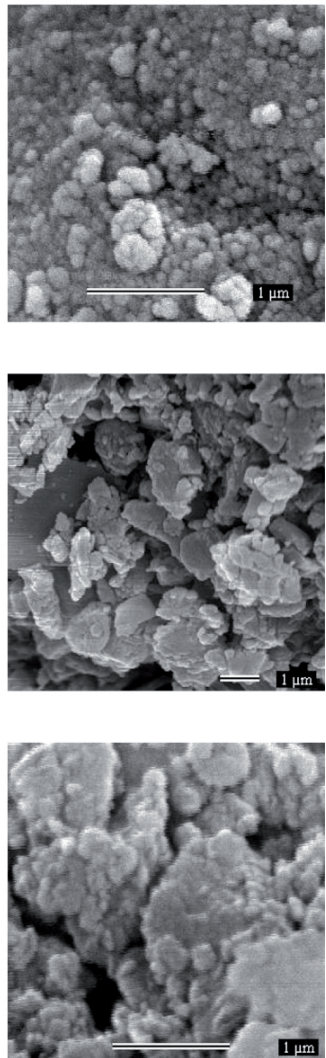

Figure 6. ${ }^{57} \mathrm{Fe}$ Mössbauer spectra acquired at $6 \mathrm{~K}$ for the Collipulli clay fraction samples before (Untreated or UT) and after CA- and AOX- treatments (a), respectively. Scanning Electron Microscopy micrographs of same samples (b) (Adapted from: Pizarro et al., 2008b).

Spectra analysis reveals relatively complex mineral assemblages, with heterogeneous chemical compositions. Such adjustment renders patterns mainly formed by an intense central doublet, due to paramagnetic $\mathrm{Fe}^{3+}$ in silicates and/or superparamagnetic iron oxides. The less intense broad-line sextet may be due to coexisting magnetically ordered form of iron oxides. The fitting method identified spectral contributions from magnetically ordered phases involving two main steps: (i) a model-independent approach which calculated a hyperfine field distribution. Then (ii) the hyperfine parameters were estimated considering the most probable magnetic fields. 
The fit was accomplished using theoretical Lorentzian-shaped resonance lines. Hyperfine parameters determined for citrate ascorbate (CA) and ammonium oxalate (AOX) treated- Collipulli clay samples are presented in Table 4.

As it was presented by Pizarro et al. (2008b), hyperfine parameters are consistent with goethite, maghemite and hematite iron oxides, along with some poorly crystalline iron-bearing compounds, which may likely be of the oxy-hydroxide group. The adjusted spectra at $6 \mathrm{~K}$ indicate that relative area of the hematite subspectrum for the $\mathrm{CA}$, and AOX treated samples was 22 and $30 \%$, respectively. Therefore, CA treatment was more efficient than AOX dissolving $\mathrm{Fe}_{3} \mathrm{O}_{4}$, particularly. Despite $\mathrm{AOX}$ and CA methods have more or less the same effect; CA is more efficient on preferential dissolution of finer particles. As a result, grains from CA treated with clay had sharper edges than those treated with AOX. On the other hand, AOX tends to preferentially remove magnetically ordered species with low hyperfine fields, which correspond to poorly crystalline iron oxide species (Table 4); CA has no effect on removing those on the characterised samples.

Table 4. Mössbauer parameters for spectra acquired at $6 \mathrm{~K}$ for the CA- and AOX- treated Collipulli clay samples. (Adapted from: Pizarro et al., 2008b).

\begin{tabular}{|c|c|c|c|c|c|}
\hline Sample & Subspectrum & $\delta / \mathrm{mm} \mathrm{s}^{-1}$ & $2 \varepsilon \mathrm{Q} / \mathrm{mm} \mathrm{s}^{-1}$ & $\mathrm{~B}_{\mathrm{hf}} / \mathrm{T}$ & RA/\% \\
\hline \multirow[t]{7}{*}{$\mathrm{CA}$} & $\mathrm{Fe}(\mathrm{III})$ & $0.44(1)$ & $0.82(2)$ & & $11.8(4)$ \\
\hline & Gt & $0.52(1)$ & $-0.21(2)$ & $50.5(1)$ & $22(4)$ \\
\hline & $\mathrm{Hm}$ & $0.52(1)$ & $-0.17(2)$ & $53.1(1)$ & 21(3) \\
\hline & {$[\mathrm{Mh}]$} & $0.37(1)$ & $-0.05(2)$ & 49.1(1) & $5(1)$ \\
\hline & $\{\mathrm{Mh}\}$ & $0.39(1)$ & $-0.02(3)$ & $51.9(1)$ & $8(2)$ \\
\hline & Lower Field & $0.48(2)$ & $-0.03(4)$ & $45.1(1)$ & 13(3) \\
\hline & Lower Field & $0.50(2)$ & $-0.20(2)$ & $47.8(1)$ & $20(5)$ \\
\hline \multirow[t]{5}{*}{ AOX } & $\mathrm{Fe}(\mathrm{III})$ & $0.50\left(^{*}\right)$ & $0.60(*)$ & & $10.3(6)$ \\
\hline & Gt & $0.52(2)$ & $-0.28\left(^{*}\right)$ & $48.1(2)$ & $30(4)$ \\
\hline & $\mathrm{Hm}$ & $0.53(2)$ & $-0.18\left(^{*}\right)$ & $52.3(1)$ & $32(3)$ \\
\hline & {$[\mathrm{Mh}]$} & $0.43(3)$ & $-0.0\left(^{*}\right)$ & 49(1) & 11(2) \\
\hline & $\{\mathrm{Mh}\}$ & $0.38(1)$ & $-0.0(*)$ & $52.0(2)$ & $18(2)$ \\
\hline
\end{tabular}

$\left(\mathbf{F e}(\mathbf{I I I})=\right.$ any subspectrum due to (super)paramagnetic $\left.\mathrm{Fe}^{3+}\right)(\mathbf{G t}=$ goethite $)(\mathbf{H m}=$ hematite $)(\mathbf{M h}=$ maghemite $)$

(Lower Field = any not-assigned subspectrum, with lower hyperfine field value than the previous) (magnetically ordered phases) ([]iron in tetrahedral site of maghemite) ( \{\} iron in octahedral sites of maghemite)

(Numbers in parentheses ( ) refer to errors over the last significant digit) (*Fixed value during least-squares fitting convergence) 
An analogous behaviour is observed for $\mathrm{Si}$ and $\mathrm{Al}$ extracted by these methods (Pizarro et al., 2008a). Untreated Collipulli clay-size fraction sample contain 5.6, 4.2 and $13.6 \%$ of $\mathrm{Fe}, \mathrm{Al}$ and $\mathrm{Si}$, respectively. After CA treatment values decrease slightly to $1.9,1.5$, and $1.1 \%$ respectively. However, after AOX method, values shift to $0.7,0.4$ and $0.1 \%$. Thus, there is a clear difference on the extraction efficiency after each of the chemical methods when treating Ultisol samples. Reyes and Torrent (1997) also found differences on extraction efficiency between the AOX and CA methods when applied to Spodosol and Andisol samples, with molar ratios of $\mathrm{Si}$ and $\mathrm{Al}$ consistent for allophane composition. Thus, an important difference is observed between CA and AOX treatment method is that the second tends to preferentially dissolve allophane and imogolite. Moreover, iron oxide removed after AOX on Andisol and Ultisol samples can be related to the organic carbon. Certini et al. (2001) have noted the influence of organic carbon content on iron oxide crystallinity. This author reports that pine plantations around Mount Etna (Italy) had a notorious effect on morphological, mineralogical and chemical properties of volcanic soils, describing that vegetation had direct responsibility on non-crystalline iron oxide deposition processes. Results on iron oxides extracted with AOX, DCB methods and organic matter for Collipulli, Osorno and Frutillar samples are given on Table 5 (Pizarro et al., 2003). DCB method (described on section 2) removes free iron oxide contents and is employed for assessing the relationship between iron oxides crystalline degree and organic matter contents.
Table 5. Organic carbon contents and iron (expressed as $w t \%$ of $\mathrm{Fe}_{2} \mathrm{O}_{3}$ ) removed by AOX and DCB treatments, respectively (Adapted from: Pizarro et al., 2003)

\begin{tabular}{lccc}
\hline Sample & $\begin{array}{c}\mathrm{OC} \\
(\mathrm{wt} \%)\end{array}$ & $\begin{array}{c}\mathrm{Fe}_{\mathrm{AOX}} \\
(\mathrm{wt} \%)\end{array}$ & $\begin{array}{c}\mathrm{Fe} \text { CB } \\
(\mathrm{wt} \%)\end{array}$ \\
\hline Collipulli & 2.0 & 1.4 & 7.3 \\
Osorno & 2.3 & 2.0 & 4.8 \\
Frutillar & 7.9 & 0.5 & 0.6 \\
\hline
\end{tabular}

It is known that $\mathrm{Fe}_{\mathrm{AOX}}$ and $\mathrm{Fe}_{\mathrm{DCB}}$ represent non-crystalline and free iron oxides contents, respectively. Its ratio $\mathrm{Fe}_{\mathrm{AOX}} / \mathrm{Fe}_{\mathrm{DCB}}$ is also named as the "activity ratio" (Borggaard, 1985). It has been found that this "activity ratio" has a direct relation to OC content on volcanic soils (Pizarro et al., 2003). On this sense, the activity ratio for Collipulli, Osorno and Frutillar samples was $0.19,0.42$ and 0.83 , respectively. Then, Borggaard ratio behaves as expected, since OC contents for same samples were 2.0, 2.3 and. 7.9, respectively. The highest $\mathrm{Fe}_{\mathrm{AOX}} / \mathrm{Fe}_{\mathrm{DCB}}$ ratio values, corresponds to less developed Andisols with a mineralogy mainly dominated by non-crystalline compounds, such as it was determined by Mössbauer spectrum interpretation, giving a ferrihydrite-like mineral after $\mathrm{NaOH}$ treatments of Osorno samples (see Section 3.4.1.). The direct relationship between $\mathrm{Fe}_{\mathrm{AOX}} / \mathrm{Fe}_{\mathrm{DCB}}$ and $\mathrm{OC}$ (typically present on allophanic soils such as Andisols, Merino et al. (2016) content is presumed to be responsible from the inhibitory effect that organic matter has on $\mathrm{Fe}$ oxides 
crysallization processes. Many authors have formed these types of relationships between selective extraction procedures (DCB, AOX) to formulate activity ratios to correlate them with OC\% and other soil parameters in order to arrive to more general conclusions. For instance, Drouza et al. (2007) proposed the relation $\left(\mathrm{Fe}_{\mathrm{DCB}}-\mathrm{Fe}_{\mathrm{AOX}}\right) * 100 / \mathrm{Fe}_{\mathrm{DCB}}$ as a parameter to determine degree of crystallisation of iron oxides present on soil samples from the volcanic island of Nisyros (Greece), concluding that the results did not permitted to classify the samples as Andisols. On a complete soil genesis and mineralogical study of a volcanic field on northern California (USA), Wilson et al. (2017) uses the $\mathrm{Fe}_{\mathrm{AOX}} / \mathrm{Fe}_{\mathrm{DCB}}$ ratio in order to describe presumed differences between pedons of diverse lithosequence. The authors established that samples from the whole field extension (20 km separated) and depth (until $120 \mathrm{~cm}$ ) had similar $\mathrm{Fe}_{\mathrm{AOx}} /$ $\mathrm{Fe}_{\mathrm{DCB}}$ ratio values, implying that sharing climate and biological factors, diverse volcanic parent materials produces soils by weathering processes with proportional amounts of non-crystalline oxides.

Therefore, since AOX treatment proved to eliminate non-crystalline iron oxides species, while leaving the crystalline forms unaffected, and considering also that AOX method preferentially removes non-crystalline $\mathrm{Si}$ and Al phases, results after AOX treatment were selected for determining the mineralogical composition of iron oxide on the clay fraction. These results gave that Maghemite is now an important contribution to the mineralogical description of iron oxide from Collipulli clay particles. An interesting fact is that the partially oxidized magnetite contents observed for magnetic sandy separates and the strongly oxidized magnetite species determined for silt fractions (after $\mathrm{NaOH}$ treatment) where not found on clay fraction. Possibly the maghemite found on the clay-size fraction comes from the complete oxidation of the magnetite contents found on the sand- and silt-size soil fractions. It seems that the assumption made is confirmed: for an Ultisol, the higher level of physical weathering of the material, providing more labile particle to chemical weathering, produces highly oxidized iron oxide minerals, as depicted on Figure 7.

If observations made by analyses on volcanic ashes are recalled, it can be noticed a logical evolution of these soil by just paying attention on their iron oxides contents. Volcanic ashes possess magnetite (among other constituents) as the protagonist iron oxide, thus giving more sense to the findings on soils: To magnetite from the precursor material (volcanic ashes), it follows partially oxidized magnetite on sand fraction, strongly oxidized magnetite on silt fraction, and maghemite on clay fraction of the respective Ultisol, Figure 7.

Such relation found for Ultisol samples, cannot be directly employed on Andisols. The main reason corresponds to higher organic matter content present on Andisol, which has an inhibitory effect on iron oxide evolution towards more oxidized and crystalline mineral forms. Zanelli et al. (2006) arrived to a similar conclusion while analysing non-volcanic soil samples from southern Switzerland. These samples were "black coloured" and had many "andic" characteristics. Most impressive was that iron oxide mineralogy at different depths obeyed the relation that poorer crystalline oxide (ferrihydrite at the surface) was found were the higher organic contents are present, while the high crystalline minerals (Goethite) prevailed on deeper soil samples with lower organic matter content. Not only organic matter has an effect on soil minerals crystalline character, but also plant-roots interaction with soils on the rhizospheric space has an effect on the decomposition processes of organic matter. For instance, Merino et al. (2015) pointed out on its review that negative rhizosphere priming effect (retardation on decomposition process of soil organic matter by the interaction between plant-roots and soil 
minerals) is present on soils with poorly-crystalline mineral content (e.g. Andisols). More precisely, as Violante and Caporale (2015) suggest, plant-root exudates (soluble organic substances released by roots) form coprecipitates with short-ordered Al, Fe oxides, promoting organic carbon accumulation and preventing crystallisation processes of mineral species. On the other hand,
Filimonova et al. (2016) declared that, after its studies on a local Andisol (Eifel mountains, Germany), there is a strong interaction between nano-particulated ferrihydrite mineral and organic matter. Highly resistant organo-mineral associations are formed, preventing organic matter decomposition and mineral oxidation (chemical weathering).
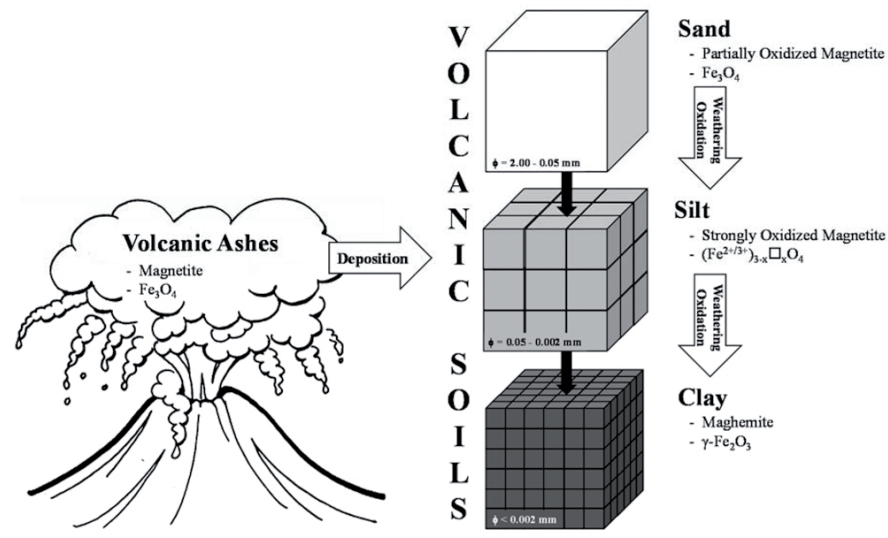

Figure 7. Iron oxide composition evolution from volcanic ashes trough soil physical and chemical weathering processes on Ultisol samples.

\section{Conclusions}

Iron oxide contents affect important properties of volcanic soil such as surface charge, providing positive variable surface charge at the soil particle. Iron oxide mineralogy has been thoroughly characterised on Chilean volcanic soils. An important feature that its directly related to the presence of iron oxides, is the magnetic character of a soil and, on this regard, Chilean Ultisols are soils with important magnetic properties. Mineralogical description of a soil's iron oxides is a complex process that may alternatively include the use of sample-pre-treatments such as physical separation of magnetic particles, chemical concen- tration of crystalline faces and characterization using complementary instrumental techniques; for example XRD, electron microscopy and, most important, ${ }^{57} \mathrm{Fe}$ Mössbauer Spectroscopy. Through a systematic study of Chilean volcanic derived materials, it has been found out that, for instance, volcanic ashes, a soil precursor of volcanic soils, have important contents of magnetite minerals. Concomitantly, Ultisols are characterised for its magnetite contents with different oxidation degrees from partially oxidized at the sand-size soil fraction, passing by strongly oxidized at the lime-size soil fraction to finally maghemite at the clay-size fraction; such behaviour gives hints on the occurring pedological formation processes of this 
volcanic soil example. On the other hand, Chilean Andisols typically contain less crystalline character minerals, paramagnetic $\mathrm{Fe}^{2+}$ and $\mathrm{Fe}^{3+}$ most probably to be a ferrihydrite-like mineral; no crystallisation and oxidation trends are observed at the different size fractions, probably due to the inhibitory effect that organic matter has on these processes.

\section{Acknowledgements}

Work supported by CEDENNA FB-0807 (Chile) and "Proyectos Basales USA1555" Universidad de Santiago de Chile. The authors thank CNPq (Brazil) for stimulating their international scientific collaboration in Latin America, as under the grant \# PROSUL 490096/2010-7. JDF is also indebted to CNPq (Brazil), for continuously supporting (grant \# 305755/2013-7) his research activities and to CAPES (Brazil) for granting his Visiting Professorship at UFVJM under the PVNS program.

\section{References}

Acebal, S.G., Mijovilovich, A., Rueda, E.H., Aguirre, M. E., Saragovi, C. 2000. Iron-oxide mineralogy of a Mollisol from Argentina: A study by selective-dissolution techniques, X-Ray Difraction, and Mossbauer Spectroscopy. Clays Clay Miner. $48,322-330$

Allison, L.E. 1965. Organic Carbon. In: C.A. Black, D.D. Evans, J.L. White, L.E. Ensminger, and F.E. Clark (eds.). Methods of Soil Analysis. Part 2. Chemical and Microbiological Properties. Agronomy Monograph 9. American Society of Agronomy, Madison, W.I., pp1367-1378.

Algoe, C., Stoops, G., Vandenberghe, R.E., Van Ranst, E. 2012. Selective dissolution of $\mathrm{Fe}-\mathrm{Ti}$ oxides - Extractable iron as a criterion for andic properties revisited. Catena. 92, 49-54.
Anastacio, A.S., Fabris, J.D., Stucki, J.W., Coelho, F.S., Pinto, I.V., Viana, J.H.M. 2006. Clay fraction mineralogy of a Cambisol in Brazil. Hyperfine Interact. 166, 619-624

Baumgarten, W., Dorner, J., Horn, R. 2013. Microstructural development in volcanic ash soils from South Chile. Soil Till. Res. 129, 48-60.

Besoain, E. 1985. Mineralogía de los suelos volcánicos del centro-sur de Chile. In: J. Tosso (Ed.) Suelos Volcánicos de Chile. INIA. pp. 107-302.

Blesa, M.A., Marinovich, H.A., Baumgartner, E.C., Maroto, A.J.G. 1987. Mechanism of dissolution of magnetite by oxalic acid-ferrous ion solutions. Inorg. Chem. 26, 3713-3717.

Blume, H.P., Schwertmann, U. 1969. Genetic evaluation of the profile distribution of aluminium, iron and manganese oxides. Soil Sci. Soc. Am. J. 33, 438-444.

Borggaard, O.K. 1985. Organic matter and silicon in relation to the crystallinity of soil iron oxides. Acta Agr. Scand. 35, 398-406.

Causevic, A., Morras, H., Mijovilovich, A., Saragovi, C. 2004. Evidences of the stability of magnetite in soil from Northeastern Argentina by Mossbauer spectroscopy and magnetization measurements. Physica B. 354, 373-376.

Cavallaro, N., McBride, M.B. 1984. Effect of selective dissolution on charge and surface properties of an acid soil clay. Clays Clay Miner. 32, 283290.

Certini, G., Fernandez Sanjurjo, M.J., Corti, G., Ugolini, F.C. 2001. The contrasting effect of broom and pine on pedogenic processes in volcanic soils (Mt. Etna, Italy). Geoderma. 102, 239-254.

Cornell, R.M., Schwertmann, U. 1996. The Iron Oxides. WILEY-VCH Verlag GmbH \& Co. KGaA, Weinheim. Pp. 572. 
Escudey, M., Galindo, G. 1983. Effect of iron oxide coatings on electrophoretic mobility and dispersion of al $\neg$ lophane. J. Colloid Interface Sci. 93, 78-83.

Escudey, M., Galindo, G. 1994. Net surface charge characteristics of allophane and synthetic aluminosilicates. J. Chil. Chem. Soc. 39, 63-70.

Escudey, M., Galindo, G., Förster, J. E., Briceño, M., Díaz, P., Chang, A. 2001. Chemical forms of phosphorus of volcanic ash-derived soils in Chile. Commun. Soil Sci. Plant Anal. 32, 601-616.

Escudey, M., Förster, J. E. Galindo, G. 2004. Relevance of organic matter in some chemical and physical characteristics of ash-derived soils. Commun. Soil Sci. Plant Anal. 35, 781-797.

Dahlgren, R.A., Saigusa, M., Ugolini, F.C. 2004. The nature, properties and management of volcanic soils. Adv. Agron. 82, 113-182.

De la Torre, I.D., Del Campillo, M.D., Barron, V., Torrent, J. 2010. Predicting the ocurrence of iron chlorosis in Grapevine with test based on soil iron forms. J. Int Sci. Vigne Vin. 44, 77-85.

Drouza, S., Georgoulias, F.A., Moustakas, M.K. 2007. Investigation of soils developed on volcanic materials in Nisyros Island, Greece. Catena. $70,340-349$.

Fabris, J.D., Mussel, W.N., Coey, J.M.D., de Jesus Filho, M.F., Goulart, A.T. 1997. Iron-rich spinels from Brazilian soils. Hyperfine Interact. 110, 33-40.

Ferreira, B.A., Fabris, J.D., Santana, P., Curi, N.2003. Óxidos de ferro das frações areia e silte de um Nitossolo desenvolvido de basalto. R. Bras. Ci. Solo. 27, 405-413.

Filimonova, S., Kaufhold, S., Wagner, F.E., Hausler, W., Kogel-Knabner, I. 2016. The role of allophane nano-structure and $\mathrm{Fe}$ oxide speciation for hosting soil organic matter in an allophanic Andosol. Geochim. Cosmochim. Ac. 180, 284-302.
Fleige, H., Beck-Broichsitter, S., Dörner, J., Goebel, M.O., Bachmann, J., Horn, R. 2016. Land use and soil development in southern Chile: Effects on physical properties. J. Soil Sci. Plant Nutr. 16, 818-831.

Galindo, G., Barros, E., Escudey, M. 1986. Comparación de los contenidos de diversas formas de $\mathrm{Al}$ activo y $\mathrm{Fe}$ activo en andisoles chilenos determinados y estimados por diferentes laboratorios. Cienc. Invest. Agrar. 13, 64-86.

Galindo, G., Förster, J.E., Díaz, P., Escudey, M. 1992. Determinación del punto isoeléctrico en suelos derivados de materiales volcánicos y sus fracciones. J. Chil. Chem. Soc. 37, 315-322.

Grez, R. 1989. Proceso físico-químico en los suelos de drenaje restringido. Boletín de la Sociedad de la Ciencia del Suelo. 9, 64-86.

Grison, H., Petrovsky, E., Stejskalova, S., Kapicka, A. 2015. Magnetic and geochemical characterization of Andosols developed on basalts in the Massif Central, France. Geochem. Geophys. Geosyst. 16, 1348- 1363.

Grison, H., Petrovsky, E., Kapicka, A., Stejskalova, S. 2016. Magnetic and chemical parameters of andic soils and their relation to selected pedogenesis factors. Catena 139, 179-190.

Jackson, M.L. 1985. Soil chemical analysis, advanced course. Department of Soil Science, University of Wisconsin, Madison.

JCPDS, 1980. Mineral Powder Diffraction Files Data Book. Joint Committee on Powder Diffraction Standards, Swartmore, Pensylvania.

Kämpf, N., Schwertmann U. 1982. The 5-M-NaOH concentration treatment for iron oxides in soils. Clays Clay Miner. 30, 401-408.

Karltun, E., Bain, D.C., Gustafsson, J.P., Mannerkoski, H., Murad, E., Wagner, U., Fraser, A.R., McHardy, W.J., Starr, M. 2000. Surface reactivity 
of poorly-ordered minerals in podzol B horizons. Geoderma. 94, 265-288.

Ketrot, D., Suddhiprakarn, A., Kheoruenromne, I., Singh, B. 2013. Interactive effects of iron oxides and organic matter on charge properties of red soils in Thailand. Soil Res. 51, 222-231.

Khawmee, K., Suddhiprakarn, A., Kheoruenromne, I., Singh, B. 2013. Surface charge properties of kaolinite from Thai soils. Geoderma. 192, 120-131.

Komadel, P., Grugar, T., Mehner, H. 1998. Reductive dissolution and Mossbauer spectroscopic study of $\mathrm{Fe}$ forms in the fine fractions of Slovak Fe-rich bentonites. Clay Miner. 4, 593-599.

Kunze, G.W. 1965. Pretreatment for mineralogical anal $\neg$ ysis: in Methods of Soil Analysis. Part 1, Agronomy, Vol. 9, C. A. Black, ed., Amer. Soc. Agron., Madison, Wisconsin, 568-577.

Lemougna, P.N., MacKenzie, K.J.D., Jameson, G.N.L, Rahier, H., Chinje Melo, U.F. 2013. The role of iron in the formation of inorganic polymers (geopolymers) from volcanic ash: a ${ }^{57} \mathrm{Fe}$ Mossbauer spectroscopy study. J. Matter. Sci. 48, 5280-5286.

Levard, C., Doelsch, E., Basile-Doelsch, I., Abidin, Z., Miche, H., Masion, A., Rose, J., Borschneck, D., Bottero, J.F. 2012. Structure and distribution of allophanes, imogolite and proto-imogolite in volcanic soils. Geoderma. 183-184, 100-108.

Li, J.Y., Xu, R.K., Zhang, H. 2012. Iron oxides serve as natural anti-acidification agents in highly weathered soils. J. Soils Sediments, 12, 876-887.

Li, J.Y., Xu, R.K. 2013. Inhibition of Acidification of Kaolinite and an Alfisol Subsoil by Iron Oxides Through Electrical Double-Layer Interaction. Soil Sci. 178, 37-45.

Liu, Z.D., Hong, Z.N., Li, J.Y. Jiang, J., Xua, R.K. 2014. Interactions between Escherchia coli and the Colloids of Three Variable Charge Soils and
Their Effects on Soil Surface Charge Properties. Geomicrobiol. J. 32, 511-520.

Marques, R., Prudeencio, M.I., Waerenborgh, J.C., Rocha, F., Ferreira da Silva, E., Dias, M.I., Madeira, J., Vieira, B.J.C., Marques, J.G. 2016. Geochemical fingerprints in topsoils of the volcanic Brava Island, Cape Verde. Catena. 147, 522-535.

Martínez, O.A., Crowley, D.E., Mora, M.L., Jorquera, M.A. 2015. Short-term study shows that phytatemineralizing rhizobacteria inoculation affects the biomass, phosphorus (P) uptake and rhizosphere properties of cereal plants. J. Soil Sci. Plant Nutr. $15,153-166$.

Mella, A.L., Kühne, A. 1985. Sistemática y descripción de las familias, asocioaciones y series de suelos derivados de materiales piroclásticos de la zona central-sur de Chile. In: J. Tosso (Ed.) Suelos Volcánicos de Chile. INIA. pp. 107-302.

Merino, C. Nannipieri, P., Matus, F. 2015. Soil carbon controlled by plant, microorganism and mineralogy interactions. J. Soil Sci. Plant Nutr. 15, 321332.

Merino, C., Godoy, R., Matus, F., 2016. Soil enzymes and biological activity at different levels of organic matter stability. J. Soil Sci. Plant Nutr. 16, 14-30.

McKeague, J.M., Day, J.H. 1966. Dithionite and oxalate-extractable $\mathrm{Fe}$ and $\mathrm{Al}$ as aids in differentiating var $\neg$ ious classes of soils. Can. J. Soil Sci. 46, 13-22.

Mehra, O.P., Jackson, M.L. 1958. Iron oxide removal from soils and clays by a dithionite-citrate system buffered with sodium bicarbonate in: Clays and Clay Minerals, Proceedings of the $7^{\text {th }}$ National Conference, Washington, D.C., pp. 317-327.

Mijovilovich, A., Morras, H., Causevic, H., Saragovi, C. 1999. Mossbauer study of the Fe mineralogy in two different Argentine soils. Hyperfine Interact. $122,83-95$. 
Mora, M., Galindo, G., Escudey, M. 1992. El rol del hierro y la materia organica en la adsorcion de fosfatos en suelos sintéticos alofanicos-modelo. Agricultura Técnica. 52, 416 - 421.

Murad, E. 2005. Characterization of a standard bauxite and its deferration products by Mossbauer spectroscopy. Miner. Eng. 18, 984-986.

Murad, E., Rojik, P. 2005. Iron mineralogy of minedrainage precipitates as environmental indicators: review of current concept and a case study from the Sokolov Basin, Czech Republic. Clay Miner. 40, 427-440.

Murad, E. 2010. Mossbauer spectroscopy of clays, soils and their mineral constituents. Clay Miner. $45,413-430$.

Norrish, K., Taylor, R.M. 1961. The isomorphous replacement of iron by aluminium in soil goethites. Eur. J. Soil Sci. 12, 294-306.

Parks, G.A. 1967. Aqueous Surface Chemistry of Oxides and Complex Oxide Minerals Isoelectric Point and Zero Point of Charge. In: W. Stumm (ed.). Equilibrium Concepts in Natural Water Systems. Adv. Chem. Ser. 6, pp: 121-160.

Pizarro, C., Furet, N.R., Venegas, R., Fabris, J.D., Escudey, M. 2000a. Some caution on the interpretation of Mössbauer spectra in mineralogical studies of volcanic soils. J. Chil. Chem. Soc. 45, 243-250.

Pizarro, C., Escudey, M., Fabris, J.D., Almeida A. B. 2000b. Effects of sodium hydroxide selective chemical treatment on sample from some Chilean soils. Commun. Soil Sci. Plant Anal. 31, 3113-3119.

Pizarro, C., Escudey, M., Fabris, J.D. Almeida, A.B. 2001. Iron-rich spinel phases from the sand fraction of three Chilean soils developing on volcanic materials. Commun. Soil Sci. Plant Anal. 32, 2741-2754.
Pizarro, C., Escudey, M., Fabris, J.D. 2003. Influence of organic matter on the iron oxides mineralogy of volcanic soils. Hyperfine Interact. 148, 53-59.

Pizarro, C., Fabris, J.D., Stucki, J., Garg V.K., Morales C., Aravena S., Gautier J.L., Galindo G. 2008a. Distribution of Fe-bearing compounds in an Ultisol as determined with selective chemical dissolution and Mössbauer spectroscopy. Hyperfine Interact. 175, 95-101.

Pizarro, C., Fabris, J.D., Stucki, J.W, Garg V.K., Galindo, G. 2008b. Ammonium oxalate and citrate-ascorbate as selective chemical agents for the mineralogical analysis of clay fractions of an Ultisol and Andisols from Southern Chile. J. Chil. Chem. Soc. 53, 1581-1584.

Reyes, I., Torrent, J. 1997. Citrate-ascorbate as a highly selective extractant for poorly crystalline iron oxides. Soil Sci. Soc. Am. J. 61, 1647-1654.

Sadzawka, A., Besoain, E. 1981. Espectrofotometría infraroja diferencial y disolución selectiva aplicados al análisis mineralógico de algunos Dystrandepts de la X Región. $3^{\circ}$ Simposio Nacional de la Ciencia del Suelo, Santiago. Sociedad Chilena de la Ciencia del Suelo. Pp. 50-51.

Sadzawka, A., Porte, L. 1985. Aluminio activo y hierro en suelos volcánicos. Agricultura Técnica. 45, 4, 329-334.

Saragovi, C., Mijovilovich, A. 1997. A Warning on the use of Mössbauer spectroscopy in semiquantitative analysis of soils. Clays Clay Miner. 45, 480-482.

Schwertmann, U. 1973. Use of oxalate for Fe extraction from soils. Can. J. Soil Sci. 53, 244-246.

Silva, A.C., Bispo, F.H.A., De Souza, S., Ardisson, J.D., Viana, A.J.S., Pereira, M.C., Costa, F.R., Murad, E., Fabris, J.D. 2013. Iron mineralogy of a grey Oxisol from the Jequitinhonha River Basin, Minas Gerais, Brazil. Clay Miner. 48, 713-723. 
Silva, A.C., Escudey, M., Förster, F.E., Pizarro, C., Ardisson, J.D., Barral, U.M., Pereira, M.C., Fabris, J.D. 2014. Iron-bearing minerals in ashes emanated from Osorno volcano, in Chile. Hyperfine Interact. 224, 153-159.

Silva, A.C., Bispo, F.H.A., Fabris, J.D., De Souza, S., Mebdes-Pires, M.J., Pereira, M.C., Guimaraes, A.O., Vargas, H., Ardisson, J.D. 2015. Grey Oxisol from the Jequitinhonha Valley, Minas Gerais, Brazil: a conceptual challenge to the soil classification system? Clay Miner. 40, 431-440.

Singer, M.J., Bowen, L.H., Verosub, K.L., Fine, P., Tenpas, J. 1995. Mössbauer Spectroscopic Evidence for Citrate-Bicarbonate-Dithionite Extraction of Maghemite from Soils. Clays Clay Miner. $43,1-7$.

U.S. Department of Agriculture, Natural Resources Conservation Service. National soil survey handbook, title 430-VI. Available at: http:// www.nrcs.usda.gov/wps/portal/nrcs/detail/soils/ ref/?cid=nrcs142p2_054242

U.S. Department of Agriculture, Natural Resources Conservation Service. 2006. The twelve orders of Soil Taxonomy. Available at: https:// www.nrcs.usda.gov/wps/portal/nrcs/detail/soils/ edu/?cid=nrcs142p2_053588
Vandenberghe, R.E., De Grave, E. 2013. Application of Mössbauer Spectroscopy in Earth Sciences, in: Yoshida, Y., Langouche, G. (Eds.) Mössbauer Spectroscopy. Springer-Verlag, Berlin, Heidelberg, pp. 91-185.

Violante, A., Caporale, A.G. 2015. Biogeochemical processes at soil-root interface. J. Soil Sci. Plant Nutr. 15, 422-448.

Wada, K., Harward, M.E. 1974. Amorphous clay con $\neg$ stituents of soils: in Advances in Agronomy. N. C. Brady (Ed.), Academic Press, New York, Vol. 26 211-260.

Wang, Y.P., Xu, R.K., Li, J.Y. 2013. Effect of Fe/Al Hydroxides on Desorption of $\mathrm{K}^{+}$and $\mathrm{NH}^{4+}$ from two Soils and Kaolinite. Pedosphere. 23, 81-87.

Wilson, S.G., Lambert, J.J., Nanzyo, M., Dahlgren, R.A. 2017. Soil genesis and mineralogy across a volcanic lithosequence. Geoderma. 285, 301-312.

Yan, M., Sun, C., Dong, J., Xu, J., Ke, W. 2015. Electrochemical investigation on steel corrosion in iron-rich clay. Corros. Sci. 97, 62-73.

Zanelli, R., Egli, M., Mirabella, A., Abdelmoula, M., Plotze, M., Notzli, M. 2006. 'Black' soils in the southern Alps: Clay mineral formation and transformation, X-ray amorphous $\mathrm{Al}$ phases and $\mathrm{Fe}$ forms. Clays Clay Miner. 54, 703-720. 